\title{
EVALUASI INFRASTRUKTUR KNOWLEDGE SHARING PEGAWAI PADA DINAS PERPUSTAKAAN PROVINSI SUMATERA SELATAN
}

\author{
Duana Meilia', Leon Andretti Abdillah ${ }^{2 *}$, Andri $^{3}$ \\ ${ }^{1-3}$ Program Studi Sistem Informasi, Universitas Bina Darma \\ Jalan Ahmad Yani No. 3, Plaju, Palembang \\ 1' $\underline{\text { duana.meilia@yahoo.co.id, }}{ }^{2 *}$ leon.abdillah@yahoo.com, ${ }^{3}$ andri@binadarma.ac.id
}

\begin{abstract}
ABSTRCT
The Regional Library of South Sumatra or Dinas Perpustakaan Provinsi Sumatera Selatan is one of the institutions of government are aware of the importance of a documentation of data and information for the sustainability activities in an organization. Currently the personnel department in Dinas Perpustakaan Provinsi Sumatera Selatan still not using an integrated system to share information among their peers, such as information regarding metting schedule, schedule events / activities that will be held by Dinas Perpustakaan Provinsi Sumatera Selatan, employee training activities, briefings and others. In addition employees did not have the means and the platform to discuss issues related to the library to the other fellow workers. This of course will result in the delivery of information to be sluggish. To optimize the role required a concept that can be implemented to run the process of knowledge management. The concept of knowledge sharing is a concept that is implemented for the governance of library Dinas Perpustakaan Provinsi Sumatera Selatan to facilitate the dissemination of knowledge implementation shortcomings that still has not been maximized. This study uses a methodology KM Cycle or Knowledge Management Cycle consists of eight stages, namely Evaluate Existing Infrastructure, Form The KM Team, Knowledge Capture, Design KM Blue Print, Verify AND Validate KM System, Implement The KM System, Manage Change and Reward strucutre, and Post System Evaluation. The results show that current infrstructures are able to support the development of KMS in Dinspustaka.
\end{abstract}

Keywords: Knowledge Sharing, KMS, Infrastructure evaluation, DINPUSTAKA.

\section{PENDAHULUAN}

Dalam lingkungan bisnis yang global sekarang ini, setiap perusahaan dan organisasi dituntut untuk mampu bersaing dalam meningkatkan kinerja dan mampu menghasilkan sebuah informasi yang berguna bagi lingkungan kerjanya. Penerapan sistem informasi (SI) tersebut dilakukan untuk mendukung strategi bisnis perusahaan atau organisasi, proses bisnis, struktur dan budaya perusahaan dalam rangka meningkatkan nilai bisnis dari perusahaan atau organisasi tersebut. Dukungan strategis dari penerapan SI pada perusahaan atau organisasi tersebut dalam bentuk peningkatan efisiensi dan efektivitas dalam pelaksanaan berbagai tugas atau aktifitas harian perusahaan. Tend terbaru mengharuskan setiap instansi untuk membangun sendiri pengetahuan (knowledge) agar dapat berkembang menjadi organisasi yang kompetitif. Pengetahuan harus dibangun sendiri, sering membutuhkan interaksi yang intensif dan melelahkan di antara anggota organisasi (Nonaka \& Takeuchi, 1995). Setelah pengatahuan yang dibutuhkan tersedia, maka organisasi perlu mengelola pengetahuan tersebut.

Salah satu cara agar sebuah organisasi dapat menjalankan fungsinya dengan baik adalah dengan memanfaatkan knowledge management (KM) atau manejemen pengetahuan. KM adalah upaya untuk meningkatkan pengetahuan yang berguna dalam organisasi. Cara untuk melakukan hal ini mencakup mendorong komunikasi, menawarkan kesempatan untuk belajar, dan mempromosikan berbagi artefak pengetahuan yang tepat (McInerney, 2002). Pada dasarnya KM adalah usaha untuk mengumpulkan, menyimpan, memproses, mengambil, mendistribusikan serta menggunakan kembali knowledge. Pada penelitian ini, fokus penelitian dilakukan pada konsep knowledge sharing. Knowledge sharing pertukaran atau pemindahan proses fakta, opini, ide, teori, princples dan model dalam dan antara organisasi termasuk trial and error, umpan balik, dan saling penyesuaian baik pengirim dan penerima pengetahuan (Pradana, 2012). Selanjutnya, Information and knowledge sharing dianggap sebagai penyebaran informasi dan pengetahuan dari sumber ke tujuan. Sumber bisa orang atau individu atau kelompok dalam sebuah organisasi. Tujuan bisa juga mirip dengan sumber tetapi mereka mungkin dari organisasi yang sama atau dari luar organisasi tertentu (Abdillah, 2014). Selain itu dalam knowledge sharing mekanisme penyampaian informasinya dapat berupa face to facemetting/communications, pertukaran dokumen, surat surat dan melalui presentasi, sedangkan jika teknologi tersebut diterapkan penyampaian tersebut dapat berubah menjadi video conferencing, akses web dan penggunaan praktikal database.

Pada pengembangan knowledge management systems (KMS), organisasi perlu melibatkan teknologi informasi. Karena teknologi adalah multifaset, organisasi harus berinvestasi dalam infrastruktur yang komprehensif yang mendukung berbagai jenis pengetahuan dan komunikasi yang penting (Gold, Malhotra, \& 
Segars, 2001). Organizational knowledge, juga dikenal sebagai intellectual capital, adalah aset perusahaan yang sangat penting, dan karena itu, organisasi memerlukan infrastruktur untuk menciptakan, struktur, menyebarluaskan, dan menerapkan pengetahuan pada waktu yang tepat kepada orang yang tepat (Lee \& Hong, 2002).

Sejumlah peneliitan telah membahas pengenai KMS seperti: 1) Knowledge sharing di institusi pendidikan tinggi (Abdillah, 2014), 2), Aspek sumber daya manusia (Sesar, 2014), 3) Pengelolaan rekonsiliasi aset (Fitriyani, Abdillah, \& Andri, 2016). Untuk penelitian kali ini, penulis akan membahas evaluasi infrastruktur KMS di lingkungan perpustakaan daerah Sumatera Selatan.

Pemanfaatan dan penerapan teknologi informasi (TI) di Dinas Perpustakaan (DINPUSTAKA) Provinsi Sumatera Selatan telah menerapkan software atau aplikasi khusus yang dapat memudahkan kegiatan atau aktifitas bisnis yang terjadi di perpustakaan. Seperti aplikasi peminjaman buku yang berguna bagi admin dalam mencatat data pelajar atau masyarakat umum yang meminjam buku, dan sebagai aplikasi untuk mencatat data keanggotaan perpustakaan. Akan tetapi, sistem tersebut diperuntukkan bagi masyarakat umum dan pelajar sebagai sebuah sistem untuk mencatat data mereka.

Saat ini bagian pegawai masih belum menggunakan sebuah sistem terpadu dalam membagi pengetahuan dan informasi antar sesama mereka, seperti informasi mengenai jadwal metting, jadwal kegiatan (event) yang akan diadakan oleh DINPUSTAKA kegiatan jadwal rapat (metting), dan lain-lain. Selain itu pegawai tidak mempunyai sarana forum diskusi yang dapat mendiskusikan permasalahan terkait perpustakaan kepada sesama pegawai lainnya. Hal ini tentu saja akan mengakibatkan penyampaian informasi menjadi lamban. Salah satu cara dalam mengatasi masalah tersebut adalah dengan merancang sebuah sistem informasi yang dapat mengakomodasi sesama pegawai dalam men-sharing pengetahuan. Cara tersebut antara lain dengan menerapkan knowledge sharing.

Berdasarkan kondisi dan latar belakang yang telah dijelaskan, maka penulis akan melakukan penelitian dengan judul "Evaluasi Infrastruktur Knowledge Sharing Pegawai pada Dinas Perpustakaan Provinsi Sumatera Selatan".

\section{METODOLOGI PENELITIAN}

\section{A. Tempat Penelitian}

Penelitian ini dilakukan di Badan Perpustakaan Provinsi Sumatera Selatan (BANPUSTAKA) yang beralamat di Jl. Demang Lebar Daun No 47, Lorok Pakjo, Ilir Barat 1 Kota Palembang, Sumatera Selatan 30151. Waktu penelitian ini dimulai dari bulan Oktober 2016 sampai dengan bulan Februari 2017.

\section{B. Metode Pengumpulan Data}

Metode pengumpulan data yang digunakan dalam menyelesaikan penelitian ini antara lain: 1) Wawancara: merupakan suatu pengumpulan data yang dilakukan dengan cara tanya jawab atau dialog secara langsung dengan pihak pihak yang terkait dengan penelitian yang dilakukan, 2) Pengamatan yaitu metode pengumpulan data dengan mengadakan tinjauan secara langsung ke objek yang diteliti, dan 3) Studi Pustaka. Untuk mendapatkan data data yang bersifat teoritis maka penulis melakukan pengumpulan data dengan cara membaca dan mempelajari buku-buku, makalah, jurnal ataupun referensi lain yang berhubungan dengan masalah dan penelitian yang dibahas.

\section{Metode Evaluasi}

Metode evaluasi yang digunakan pada penelitian ini diadopsi metode pengembangan sistem "KMS Road Map". Menurut Tiwana (2002) "KMS Road Map" terdiri dari Sepuluh Tahapan dan terbagi ke dalam 4 (empat) fase. Keempat fase tersebut: 1) Infrastructure evaluation, 2) System Analsis, Design, and Development, 3) Deployment, dan 4) Evaluation.

Namun pada penelitian yang akan dilakukan penulis pada sistem ini akan menggunakan tahapan sampai fase pertama yang dimulai dari step pertama sampai kedua. Fase pertama tersebut terdiri dari beberapa tahapan, yakni : 1) Analysze The Existing Infrastructure, dan 2) Align Knowledge Management and Business Strategy (lihat Gambar 1).

Pada tahapan "analyze existing infrastructure"ada beberapa hal yang perlu diperhatikan : 1) Knowledge apa yang akan dihapuskan, ditransfer, atau dipindahkan ke perusahaan lain, 2) Apakah sistem KM yang diajukan dibutuhkan di beberapa lokasi, dan 3) Apakah para ahli bisa dan berkeinginan untuk membantu membangun sistem KM. Selanjutnya pada tahapan "Align Knowledge Management and Business Strategy", terdiri atas: 1) Ubah pandangan perusahaan dari strategic programming menjadi strategic planning, 2) Terapkan pengetahuan berbasis stregth, weakness, opportunities and threats (SWOT), 3) Analisis gap atau jarak dan identifikasi bagaimana manajemen pengetahuan dapat mengisi gap tersebut, 4) Tentukan bahwasanya kodifikasi dan personifikasi fokus apakah sesuai dengan sistuasi di perusahaan, dan 5) Sebelum membangun sistem manajemen pengetahuan, tentukan pertanyaan yang tepat untuk ditanyakan. 


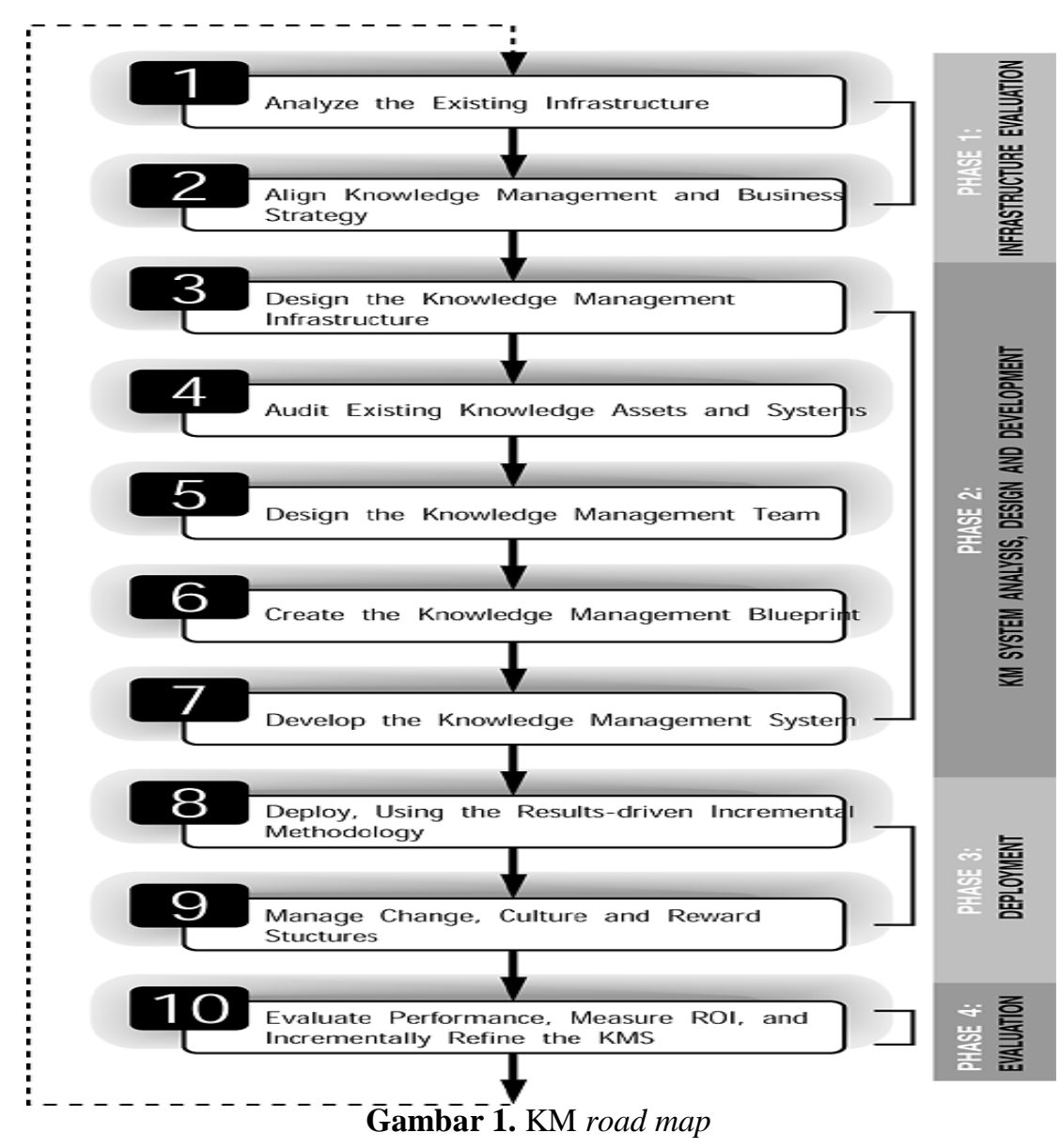

\section{PEMbahasan}

Pembahasan pada penelitian ini fokus pada fase pertama "KMS Road Map". Fase pertama terdiri atas 2 (dua) langkah, yaitu: 1) Analyze Existing Infrastructure, dan 2) Align Knowledge Management and Business Strategy.

Pada tahapan ini penulis menjelaskan kegiatan di Fase Analisa Infrastruktur Knowledge Sharing Pegawai pada Dinas Perpustakaan Provinsi Sumatera Selatan. Namun langkah yang dilakukan pada penelitian kali ini di Dinpustaka adalah langkah pertama dan kedua yakni : 1) Understanding the role of your company existing network, intranet dan extranet in knowledge management (memahami peran dari infrastruktur seperti jaringan di internet dan extranet), dan 2) Understanding the knowledge management framework (memahami kerangka kerja manajemen pengetahuan beserta komponennya).

\section{A. Analyze Existing Infrastructure}

Langkah pertama bertujuan untuk memahami peran dari infrastruktur yang ada untuk nantinya dilakukan analisa infrastruktur pada pengembangan KMS yang akan diterapkan. Berikut analisis dan diagnosa infrastrktur yang telah penulis lakukan pada Dinpustaka : 1) Sudah terdapat Intranet yaitu berupa jaringan virtual pribadi untuk berbagi informasi dalam lingkup lokal, 2) Memiliki akses Internet yaitu jaringan internet berupa wifi dengan jaringan yang bisa diakses baik untuk pengunjung perpustakaan maupun staff karyawan, 3) Memiliki bandwith yang cukup besar (512 Mbps) atau kecepatan internet atau kecepatan transfer data, dan 4) Sudah memiliki LAN/WAN yaitu jarigan yang dapat dipakai untuk berbagi sumber daya sesama pegawai dan staff. Perpustakaan Provinsi Sumatera Selatansaat ini telah menggunakan teknologi jaringan komputer untuk menghubungkan semua unit komputer yang ada di perpustakaan Provinsi Sumatera Selatan. Infrastruktur yang ada pada perpustakaan Provinsi Sumatera Selatansebagian besar sudah bisa mendukung proses penerapan KMS dalam berbagi pengetahuan mengenai kegiatan kepegawaian. Jaringan Komputer yang ada memungkinkan sumber daya manusia yang ada pada perpustakaan Provinsi Sumatera Selatandapat berperan dalam berbagi pengetahuan seputar apa saja yang terjadi di lingkungan kepegawaian Perpustakaan Provinsi Sumatera Selatan. Infrastruktur yang ada pada Dinas Perpustakaan Provinsi Sumatera Selatan sebagian besar sudah bisa mendukung proses penerapan KMS dalam berbagi pengetahuan mengenai 
hal hal yang berkaitan dengan kepegawaian. Jaringan Komputer yang ada memungkinkan sumber daya manusia yang ada pada Dinas Perpustakaan Provinsi Sumatera Selatan dapat berperan dalam berbagi pengetahuan seputar kepegaiwan. Berikut struktur jaraingan dan topologi pada Dinas Perpustakaan Provinsi Sumatera Selatan.

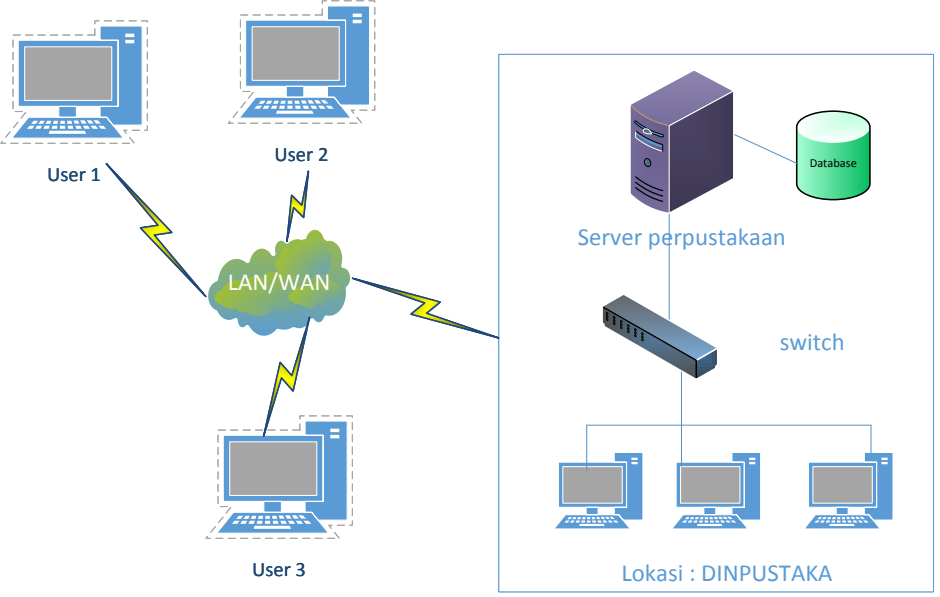

Gambar 2. Topologi Jaringan DINPUSTAKA

Selain melakukan analisa infrastruktur, pada tahapan ini penulis juga akan menjelaskan mengenai knowledge technology management dan komponen-komponennya. Knowledge technology management merupakan sebuah kerangaka teknologi manajemen pengetahuan yang berguna untuk menganalisis teknologi yang telah dipakai, aksi apa yang bisa diambil dari analisis tersebut dan tindakan apa dan infrastruktur apa yang bisa dilakukan untuk menambahkan value dari infrastruktur yang telah ada. Untuk memahami bagaimana komponen tersebut berelasi, maka penting untuk memahami setiap key function dari setiap komponen. Berikut penjelasannya: 1) Knowledge Flow: Komponen ini berguna untuk memfasilitasi arus pengetahuan di dalam KMS, 2) Information Mapping: peta informai merupakan hal yang akan menghubungkan arus informasi yang nantinya mungkin akan diterapkan pada seluruh bagian organisasi, 3) Information sources: sumber data mentah atau informasi yang akan ada di KMS, dan 4) Information and knowledge exchange: merupakan alat dan fasilitator non teknologi yang memungkinkan adanya pertukan informasi sumber pengetahuan tacit dan explicit yang dapat dipakai untuk membuat dan membagikan konteks pengetahuan sebagai sarana pengambilan keputusan. Gambar 2 memperlihatkan Knowledge Technology (Tiwana, 2000).

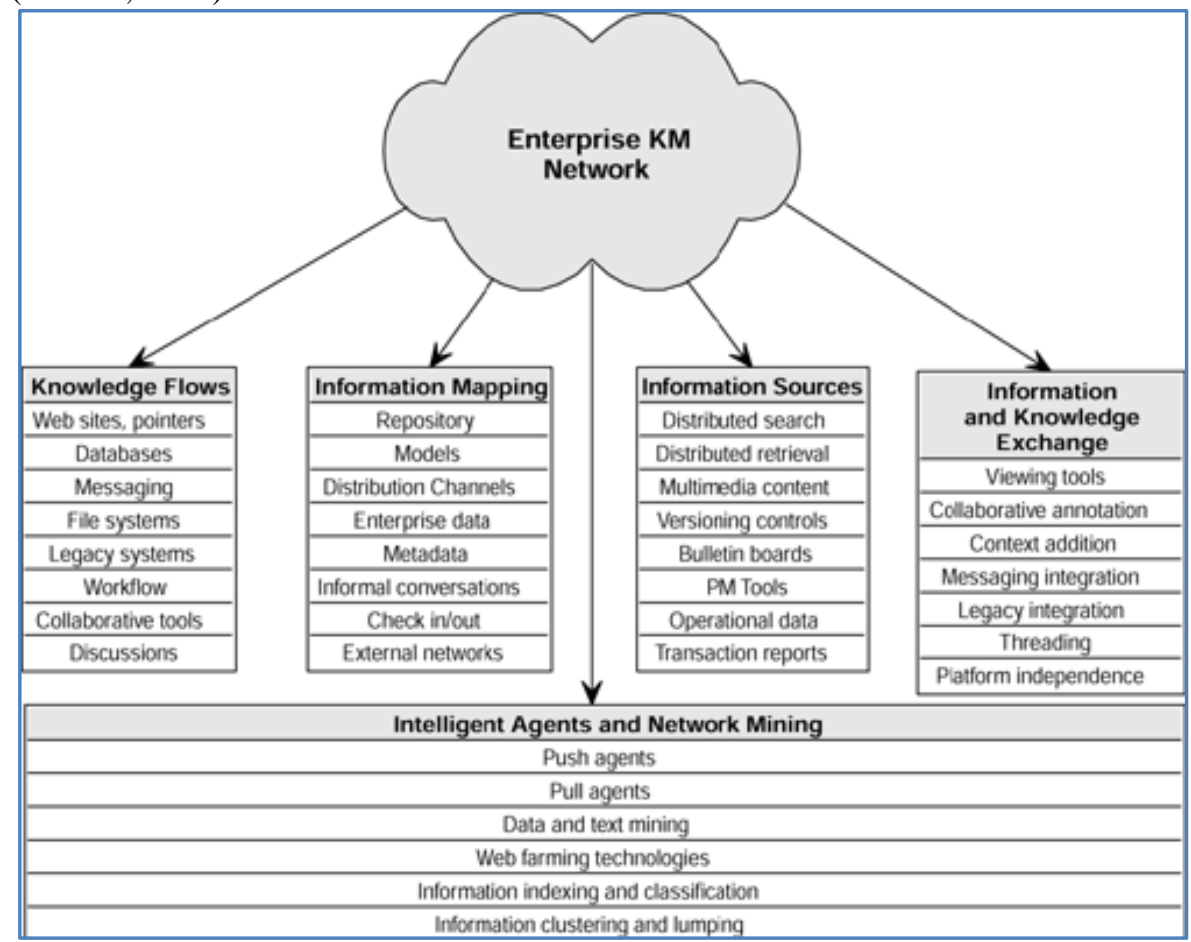

Gambar 2. Komponen Knowledge Management Technology Framework 


\section{B. Align Knowledge Management and Business Strategy}

Penulis menyesuaikan program strategis dan perencanaan strategis dengan menganalisis visi dan misi organisasi, membuat analisa SWOT dan menganalisis gap yang terdapat di Dinpustaka. Dari kesembilan tahapan tersebut yang akan penulis lakukan adalah tahapan pertama yakni menyesuaikan program strategis dan perencanaan strategis dengan menganalisis visi dan misi organisasi, membuat analisa SWOT dan menganalisis gap yang terdapat di Dinas Perpustakaan Provinsi Sumatera Selatan. Berikut penjelasan dari masing masing steps yang dilakukan. Kerangka SWOT umumnya digunakan untuk sistematis mengkarakterisasi situasi tertentu berkaitan dengan kekuatan internal dan kelemahan serta peluang eksternal dan ancaman (Schroeder, Minocha, \& Schneider, 2010).

Pada langkah pertama dari ini perlu diselaraskan antara KM dengan stategi bisnis organisasi. Cara untuk menyelaraskannya adalah dengan mengubah program strategi ke perencanaan strategis dengan melakukan analisis visi dan misi organisasi Dinas Perpustakaan Provinsi Sumatera Selatan agar knowledge yang dibangun sesuai untuk mencapai visi dan misi tersebut. Dari visi dan misi yang telah diuraikan dapat disimpulkan bahwa penerapan KM telah sejalan dengan visi dan misi yang diterapkan. KMS yang dikembangkan akan mendukung kelancaran pelaksanaan tugas dan pokok fungsi Dinas Perpustakaan Provinsi Sumatera Selatan khususnya di pada bagian staff dan karyawan selain itu dengan diterapkan KMS ini akan memacu dan memfasilitasi perkembangan perpustakaan di masa yang akan datang.

Pada langkah kedua, dalam menyelaraskan knowledge management dengan strategi bisnis suatu perusahaan dilakukan analisis strength, weakness, opportunity, threat (SWOT) untuk perancangan KMS. Uraian analisis SWOT dapat dilihat pada tabel 1.

Pada langkah ketiga, dilakukan analisia "knowledge gap". Berikut analisis cost dan benefits yang nantinya akan diterapkan pada Dinas Perpustakaan Provinsi Sumatera Selatan: 1) Biaya pembelian, di dalamnya termasuk perangkat lunak, perangkat keras, perangkat jaringan, pembelian lisensi baru, tenaga kerja, dan juga biaya tidak langsung lain, 2) Biaya implementasi, yang mencakup proses transisi ke sistem yang baru, migrasi data, dan juga biaya yang keluar dari aktivitas change management, 3) Biaya pengembangan sistem, yaitu biaya yang berhubungan dengan aktivitas membangun sistem yang baru ataupun pengembangan fitur baru pada sistem yang telah ada, dan 4) Biaya pemeliharaan, yaitu biaya yang muncul setelah implementasi yang bertujuan memastikan sistem terus berjalan sesuai fungsinya. Hal ini termasuk pembaruan lisensi perangkat lunak, biaya komunikasi, pelatihan, pemeliharaaan perangkat lunak. Sebagai keuntungan tangible, dapat dihitung penghematan yang didapat Dinpustaka dalam bentuk Cost Savings dan Cost Avoidance. Cost savings mengacu pada jumlah yang bisa dipotong secara langsung karena suatu aktivitas yang tidak diperlukan lagi atau berkurang nilainya.

Tabel 1. Analisis SWOT

\begin{tabular}{|c|c|}
\hline Strength (Kekuatan) & Weakness (Kelemahan) \\
\hline $\begin{array}{ll}\text { - } & \text { Infrastruktur telah mendukung dalam } \\
\text { pengimplementasian KMS berbagi } \\
\text { pengetahuan tentang kepegawaian } \\
\text { Staff dan pegawai telah dapat } \\
\text { menggunakan teknologi dan infrastruktur } \\
\text { yang ada di Dinpustaka }\end{array}$ & $\begin{array}{l}\text { - Perlu peningkatan atau pemahaman SDM } \\
\text { (staff dan karyawan untuk menguasai dan } \\
\text { mengenal secara keseluruhan konsep KMS } \\
\text { karena bersifat online dan juga staff dan } \\
\text { karyawan di Dinpustaka berasal dari } \\
\text { background pendidikan yang berbeda } \\
\text { - Dibutuhkan tenaga atau investasi tambahan } \\
\text { berupa tambahan waktu dan SDM untuk } \\
\text { me-maintenance aplikasi dan knowledge } \\
\text { base agar tetap ter-uptodate }\end{array}$ \\
\hline Opportunity (Peluang) & Threats (Kekuatan) \\
\hline $\begin{array}{l}\text { - Ketertarikan organisasi (Dinpustaka) untuk } \\
\text { menjalin kerja sama antar pegwai dalam } \\
\text { mengembangkan knowledge }\end{array}$ & $\begin{array}{l}\text { - Perubahan perilaku pengguna yang } \\
\text { menuntut akses informasi yang cepat dan } \\
\text { akurat } \\
\text { Bagi pihak pemerintah, investasi teknologi } \\
\text { dan informasi untuk pegawai sering } \\
\text { dianggap sebagai investasi yang tidak } \\
\text { membawa keuntungan nyata } \\
\text { Banyak virus komputer yang menyerang } \\
\text { software layanan perpustakaan yang } \\
\text { memungkinkan data perpustakaan hilang } \\
\text { - Intervensi berlebihan dalam bidang } \\
\text { kepegawaian yang bertentangan dengan } \\
\text { ketentuan yang berlaku }\end{array}$ \\
\hline
\end{tabular}




\section{SIMPULAN}

Simpulan yang dapat diambil dari penelitian ang telah dilakukan serta hasil pembahasan yang diuraikan pada bagian-bagian sebelumnya, maka dapat ditarik beberapa simpulan yang penulis uraikan dan jabarkan sebagai berikut:

1) Infrastruktur yang ada pada Dinpustaka secara keseluruhan udah layak untuk membangun suatu knowledge managemetn ssytems.

2) Terdapat 6 (enam) buah pengetahuan yang diharapkan untuk diterapkan pada KMS pada Dinas Perpustakaan Provinsi Sumatera Selatan, yaitu : a) pengetahuan tentang jadwal rapat, b) jadwal event, c) media forum dan diskusi, d) data pegawai, e) data artikel, dan f) fasilitas download.

3) Strategi pendekatan yang akan digunakan pada KMS adalah strategi berbasis kodifikasi yakni pengetahuan diterjemahkan dalam bentuk eksplisit secara berhati-hati (codified) dan disimpan dalam basis data sehingga para pencari pengetahuan yang membutuhkannya dapat mengaksesnya.

4) Untuk penelitian lanjutan, KMS perlu dibangun sehingga dapat diterapkan pada Dispustaka.

\section{DAFTAR PUSTAKA}

Abdillah, L. A. (2014). Managing information and knowledge sharing cultures in higher educations institutions. Paper presented at the The 11th International Research Conference on Quality, Innovation, and Knowledge Management (QIK2014), The Trans Luxury Hotel, Bandung, Indonesia.

Fitriyani, M., Abdillah, L. A., \& Andri. (2016). The Implementation of Knowledge Management Systems in Assets Reconciliation. Paper presented at the The 5th International Conference on Information Technology and Engineering Application (ICIBA2016), Bina Darma University, Palembang.

Gold, A. H., Malhotra, A., \& Segars, A. H. (2001). Knowledge management: An organizational capabilities perspective. Journal of Management Information Systems, 18(1), 185-214.

Lee, S. M., \& Hong, S. (2002). An enterprise-wide knowledge management system infrastructure. Industrial Management \& Data Systems, 102(1), 17-25.

McInerney, C. (2002). Knowledge management and the dynamic nature of knowledge. Journal of the American Society for Information Science and Technology, 53(12), 1009-1018.

Nonaka, I., \& Takeuchi, H. (1995). The knowledge-creating company: How Japanese companies create the dynamics of innovation: Oxford university press.

Pradana, A. R. (2012). Knowledge Sharing Pada Community Of Practices di PT. Pembangkit Jawa Bali, Unit Pembangkit Gresik. Surabaya: Universitas Airlangga.

Schroeder, A., Minocha, S., \& Schneider, C. (2010). The strengths, weaknesses, opportunities and threats of using social software in higher and further education teaching and learning. Journal of Computer Assisted Learning, 26(3), 159-174.

Sesar, V. (2014). Knowledge Management from the Aspect of Human Resource Management in Organization. Paper presented at the 8th International Quality Conference, Serbia.

Tiwana, A. (2002). The knowledge management toolkit: orchestrating IT, strategy, and knowledge platforms: Pearson Education India. 